\title{
Population structure, feeding and reproductive aspects of Serrapinnus beterodon (Characidae, Cheirodontinae) in a Mogi Guaçu reservoir (SP), upper Paraná River basin
}

\author{
Estrutura populacional, alimentação e reprodução do lambari-prata \\ Serrapinnus heterodon (Characidae, Cheirodontinae) em um reservatório \\ do rio Mogi Guaçu (SP), bacia do alto rio Paraná
}

Cristina da Silva Gonçalves ${ }^{1}$, Ursulla Pereira Souza ${ }^{2}$ and Francisco Manoel de Souza Braga ${ }^{3}$

'Programa de Pós-graduação em Zoologia, Departamento de Zoologia,

Instituto de Biociências, Universidade Estadual Paulista "Júlio de Mesquita Filho" - UNESP,

Av. 24-A, 1515, CEP 13506-900, Rio Claro, SP, Brazil

e-mail: cristina.silva.goncalves@gmail.com

${ }^{2}$ Programa de Pós-graduação em Zoologia, Departamento de Ecologia,

Instituto de Biociências, Universidade Estadual Paulista "Júlio de Mesquita Filho" - UNESP, Av. 24-A, 1515, CEP 13506-900, RioClaro, SP, Brazil e-mail: upsouza@gmail.com

\begin{abstract}
${ }^{3}$ Departamento de Zoologia, Instituto de Biociências, Universidade Estadual Paulista "Júlio de Mesquita Filho" - UNESP, Av. 24-A, 1515, CEP 13506-900, Rio Claro, SP, Brazil e-mail: fmsbraga@rc.unesp.br
\end{abstract}

\begin{abstract}
Aim: In this report, we describe the population structure, feeding and reproductive aspects of the cheirodontine Serrapinnus heterodon collected in a reservoir of a small hydro power of Mogi Guaçu River (SP); Methods: Specimens were caught bimonthly between August 2005 and July 2006 near the marginal aquatic vegetation with four traps; Results: A total of 38 specimens of $S$. heterodon were collected (mainly during the rainy season), comprising 16 males ( $32-47 \mathrm{~mm} \mathrm{SL}$ ), 18 females (32-49 $\mathrm{mm} \mathrm{SL}$ ) and four individuals with indeterminate sex $(33-45 \mathrm{~mm} \mathrm{SL})$. There were significant differences in length distribution between sexes, with males being smaller than females $\left(\bar{x}_{\text {males }}=42 \pm 4.3 \mathrm{~mm}\right.$ and $\left.\bar{x}_{\text {females }}=45 \pm 4.8 \mathrm{~mm}\right)$. Sex ratio was 1:1. Eight food items were identified in the diet, with a predominance of autochthonous items. The diet classified as omnivorous. Insects (fragments) were the most consumed item, followed by microcrustaceans (Cladocera and Ostracoda), algae (mainly diatoms) and immature insects (Diptera and Odonata). Comparing with other cheirodontines, $S$. heterodon has higher fecundity (mean $=1,231 \pm 440$ oocytes) and smaller oocytes $(61$ to $793 \mu \mathrm{m})$. Moreover, the spawning was classified as total and occurred during the rainy season which is the breeding season for the majority of fish species from the upper Paraná River basin; Conclusions: The results seem to reflect the type of environment in which $S$. heterodon inhabit, because the lentic environment afforded by the dam provides relatively stable conditions to maintaining this species, which uses aquatic vegetation as shelter from predators and as feeding and breeding sites.
\end{abstract}

Keywords: diet, fecundity, reproductive tactics, impoundment.

Resumo: Objetivo: Neste trabalho, a estrutura populacional e os aspectos alimentares e reprodutivos do queirodontíneo Serrapinnus heterodon são descritos, a partir de exemplares coletados no reservatório de uma pequena central hidrelétrica do rio Mogi Guaçu (SP); Métodos: Os exemplares foram capturados bimensalmente entre agosto de 2005 e julho de 2006 com armadilhas do tipo covo, próximos da vegetação aquática marginal; Resultados: Dentre os 38 exemplares amostrados (a maior parte durante o período chuvoso), 16 eram machos $(32-47 \mathrm{~mm}), 18$ fêmeas $(32-49 \mathrm{~mm})$ e quatro indivíduos com sexo indeterminado $(33-45 \mathrm{~mm}$ ). Os machos foram significativamente menores do que as fêmeas $\left(\bar{x}_{\text {machos }}=42 \pm 4,3 \mathrm{~mm} ; \bar{x}_{\text {femeas }}=45 \pm 4,8 \mathrm{~mm} ; \mathrm{p}<0,05\right)$ e a proporção sexual encontrada foi 1:1. Oito itens alimentares foram identificados na dieta de $S$. heterodon, sendo os itens de origem autóctone predominantes. A dieta desta espécie foi classificada como onívora. Insetos (fragmentos) foi o item mais consumido, seguido por microcrustáceos (Cladocera e Ostracoda), algas (principalmente diatomáceas) e formas 
imaturas de insetos (Diptera e Odonata). Em comparaçáo com outros queirodontíneos, S. heterodon tem fecundidade maior (média $=1.231 \pm 440$ ovócitos) e ovócitos menores (61 a $793 \mu \mathrm{m}$ ). Além disso, a desova foi classificada como total e ocorre durante o período chuvoso, que corresponde à estação reprodutiva para a maioria das espécies de peixes da bacia do alto rio Paraná; Conclusóes: Os resultados parecem refletir o tipo de ambiente em que $S$. heterodon vive, pois o ambiente lêntico propiciado pelo reservatório, oferece condições relativamente estáveis para a manutenção desta espécie, que utiliza a vegetação aquática como abrigo contra predadores e como sítio de alimentaçáo e reprodução.

Palavras-chave: dieta, fecundidade, táticas reprodutivas, represa.

\section{Introduction}

In Brazil, 2,587 fish species occur exclusively in freshwater environments and the family Characidae has the largest number of specimens (Buckup et al., 2007). The subfamily Cheirodontinae is represented by 15 genera and 46 valid species, composed mainly by small bodied size individuals $(30-40 \mathrm{~mm}$ of standard length), which occurs in most drainages of Central and South America and often abundant in lentic environments (Malabarba, 2003). According to Langeani et al. (2007), six Cheirodontinae species are recognized in the upper Paraná River basin, all native: Aphyocheirodon hemigrammus Eigenmann, 1915, Kolpotocheirodon theloura Malabarba \& Weitzman, 2000, Odontostilbe microcephala Eigenmann, 1907, Serrapinnus heterodon (Eigenmann, 1915), S. notomelas (Eigenmann, 1915), Spintherobolus papilliferus Eigenmann, 1911. This basin is a complex area due tectonic activities that have occurred since the late Cretaceous and early Tertiary, taking with it events of capture the headwaters, resulting in the distribution of its species in adjacent drainages (Langeani et al., 2007).

Cheirodontinae is a well studied subfamily and, among cheirodontines, S. notomelas is the species that currently has more information in literature. Studies with this species were conducted by Luiz et al. (1998), Oliveira et al. (2001), Casatti et al. (2003), Hahn and Loureiro-Crippa (2006), Pelicice and Agostinho (2006) and SantanaPorto and Andrian (2009) that verified its feeding aspects, and Piana et al. (2006), Andrade et al. (2008), Lourenço et al. (2008) and Benitez and Súarez (2009) which identified some population parameters of this species. Serrapinnus heterodon occurs in rivers, streams, oxbow lakes and reservoirs (Esteves, 2000; Oliveira and Garavello, 2003; Perez Junior and Garavello, 2007; Gonçalves and Braga, 2008), but it is still poorly known, with some studies regarding its diet (Alvim et al., 1998; Esteves, 2000;
Gomiero and Braga, 2008; Dias and Fialho, 2009), and its reproduction (Gomiero and Braga, 2007).

The small hydro power Mogi Guaçu was built by damming the Mogi River and its left tributary, the Peixe River. Lotic environments artificially transformed in reservoirs provide a new and changed environment that may be favorable to the development of some fish species adapted to them (Agostinho et al., 2007). Some aquatic vegetation can also proliferate in those modified environments (Cavenaghi et al., 2005) and many fish species use aquatic vegetation as shelter, feeding and reproduction sites (Lowe-McConnell, 1975; Welcomme, 2002), including cheirodontines (Delariva et al., 1994, Casatti et al., 2003; Petry et al., 2003).

Since ecological knowledge about $S$. heterodon are scarce, this paper aimed to contribute with information regarding population aspects, diet and reproduction of this species collected in a reservoir of the small hydro power Mogi Guaçu, São Paulo State, Brazil.

\section{Material and Methods}

\subsection{Sampling}

Samples were taken in the reservoir of a small hydro power Mogi Guaçu $\left(22^{\circ} 21^{\prime} \mathrm{S}\right.$ and $\left.46^{\circ} 51^{\prime} \mathrm{W}\right)$, located in the Mogi Guaçu municipality (SP). Main characteristics of this reservoir are: $5.73 \mathrm{~km}^{2}$ surface area, $32.89 \times 10^{6} \mathrm{~m}^{3}$ volume and a barrier with $150 \mathrm{~m}$. At the sampled site, bottom is muddy or sand-muddy, maximum depth is around $5 \mathrm{~m}$ and the border vegetation is dominated by sugar cane and pastures (Gonçalves and Braga, 2008). The water transparency is low and aquatic vegetation is composed mainly of marginal and floating species, such as: Brachiaria subquadripara, Eichornia crassipes, Polygonum lapathifolium, Panicum rivulare, Salvinia auriculata, Pistia stratiotes and other species less abundant (Cavenaghi et al., 2005). 
Dry and wet periods in the study area was determined according to methodology proposed by Walter and Lieth (1960), using the average of 30 years of rainfall and air temperature. Therefore, the dry period was defined by the months between April and September and the wet period from October to March in this region.

Fish samples were taken bimonthly between August 2005 and July 2006, comprising six samples. The sampling effort was standardized, and consisted of four baited traps with $60 \mathrm{~cm}$ long and $20 \mathrm{~cm}$ wide and a hand net with $2 \mathrm{~mm}$ mesh. The traps were placed near the marginal vegetation (banks of Brachiaria subquadripara), during the afternoon, and removed in the morning of the next day, remaining 12 hours. The hand net was passed 10 times near the marginal vegetation in two predefined points (Gonçalves and Braga, 2008). Fish caught were fixed in $10 \%$ formalin and preserved in $70 \%$ alcohol. Voucher specimens are deposited in the fish collection of Departamento de Zoologia, Universidade Estadual Paulista (Rio Claro/SP).

\subsection{Data collection}

In the laboratory, the total and standard length (mm TL and SL, respectively), total weight (g), sex, stomach repletion degree (SR), fat accumulated in the visceral cavity degree (FA), stage of gonadal maturity (GM), and gut length ( $\mathrm{mm}$ ) were obtained to each specimen.

Stomachs were visually classified in three categories: 1 (empty), 2 (partially filled with food) and 3 (full). The visceral cavity was examined visually, considering the categories: 1 (no fat), 2 (partially with fat) and 3 (full) (Braga, 1990). The gonadal maturation stages were defined macroscopically according to oocyte's appearance, color, vascularization and transparency of the gonads and classified as: stage A (immature), stage $\mathrm{B}$ (maturing or resting), stage $\mathrm{C}$ (mature) and stage $\mathrm{D}$ (spent) (Vazzoler, 1996). The mature ovaries (stage C) were removed, weighted (g) and kept in Gilson solution to complete dissociation of oocytes until analysis of fecundity.

\subsection{Data analysis}

The population structure of $S$. heterodon was evaluated analyzing the sex ratio and length distribution of individuals. Length of each specimen was grouped into classes with an interval of $1 \mathrm{~cm}$, considering males and females separately and then grouping the sexes. Shapiro-Wilk test was used to verify data normality and to detect differences in body sizes between sexes, the Kolmogorov-Smirnov test was used. The significance level considered was 5\% (Zar, 2010).

For each specimen, the weight/length relationship was adjusted: $W=a^{*} L^{b}$, where $W$ is the weight (g), $L$ is the length (mm SL), $a$ is the intercept and $b$ is the slope, estimated by least squares method after logarithmic transformation of data (Zar, 2010).

The diet was analyzed by examining the contents of full stomachs ( $\mathrm{SR}=3)$, according to assumptions of Feeding Importance Degree method (GPA, in portuguese) (Braga, 1999). The food items were identified up to the lowest taxonomic level possible, under a stereomicroscope, using Borror and Delong (1969), and Needham and Needham (1982). To investigate the relationship between intestine length and diet, the intestinal quotient (IQ) was calculated, as follow: $I Q=I L / T L$, where $I L$ is the intestine length $(\mathrm{mm})$, and $T L$ is the total length $(\mathrm{mm})$ of fish (Barbieri et al., 1994).

Absolute fecundity was estimated by volumetric method (Vazzoler, 1996). The total count of vitellogenic oocytes $(N)$ was performed under a stereomicroscope (16x magnification), and 100 of these oocytes were randomly selected and measured with an ocular micrometer (10x magnification) to determine oocyte's diameter. This information was used to assess the type of spawning of the species and the diameter at which the oocytes become mature. The estimated total number $(N)$ of oocytes in final of vitellogenesis phase (mature oocytes) was calculated assuming: $N=N^{*} P / 100$, where $N^{\prime}$ is the total number of oocytes counted in the sample and $P$ is the percentage of oocytes from which the diameter they are in final process of maturation, in relation to the total number of oocytes in vitellogenesis $(N)$.

The gonadosomatic relationship (GSR) was obtained: $G S R=\left(O_{W} / T_{W}\right)^{*} 100$, where $O_{W}$ is the ovarian weight $(\mathrm{g})$, and $T_{W}$ is the total weight $(\mathrm{mm})$ of the fish (Vazzoler, 1996).

\section{Results and Discussion}

A total of 38 specimens of $S$. heterodon were collected comprising 16 males (32-47 mm SL), 18 females (32-49 mm SL), and four individuals with indeterminate sex (33-45 mm SL). All specimens were captured with traps near marginal areas of the reservoir (i. e. no specimen was obtained with the hand net). Most individuals were captured during the rainy season in October (55\%) and February (42\%), and only one individual in the dry season (June). 
Sex ratio was not different than expected (1:1). The distribution of length by classes does not follow a normal distribution (Shapiro-Wilk: $\mathrm{W}=0.8814$, $\mathrm{p}=0.0015)$. There were significant differences in length distribution between sexes (KolmogorovSmirnov: $\mathrm{D}=0.5972, \mathrm{p}=0.0048$ ), with males being smaller than females $\left(\bar{x}_{\text {males }}=42 \pm 4.3 \mathrm{~mm} \mathrm{sd}\right.$, and $\bar{x}_{\text {females }}=45 \pm 4.8 \mathrm{~mm} \mathrm{sd}$ ) (Figure 1). Similar results were found by Andrade et al. (2008) to S. notomelas in a reservoir of São José do Rio Preto (SP). In fishes, sex ratio of $1: 1$ is expected when the role population is analyzed. Since females have higher growth rates than males, there is a predominance of females in larger size classes when length structure is analyzed in details (Vazzoler, 1996). Lourenço et al. (2008) and Benitez and Súarez (2009) found lower values of body size (mean = 23.2 and $26.2 \mathrm{~mm}$, respectively) to $S$. notomelas surveyed in lotic environments (streams, upper Paraná River) compared to those found in this study to $S$. heterodon. This condition may be associated with a particular biological characteristic of each species or the kind of environment they inhabit (lotic or lentic). The reservoir studied is a typical lentic environment dammed and, according to Cavenaghi et al. (2005), the water transparency is low and aquatic vegetation is composed of several species (marginal and floating species). Thus, the reservoir provides stable conditions for the maintenance of several species of small fish that, in addition to find shelter from predators in macrophyte banks (Delariva et al. 1994; Meschiatti et al., 2000; Casatti et al., 2003), can achieve larger sizes in these sites (Rozas and Odum, 1988).

The allometric equation adjustment to weight/length data resulted in the expression
$W=7^{*} 10^{-6} L^{3.2718}(\mathrm{r}=0.95)$. The constant $b$ was not significantly higher than $3(\mathrm{t}=0.096 ; \mathrm{df}=32$; $\left.\mathrm{p}=0.92 ; \mathrm{CI}_{95 \%}=2.927-3.636\right)$, therefore, the relation was considered isometric. To $S$. notomelas, Lizama and Ambrósio (1999), Lourenço et al. (2008) and Benitez and Súarez (2009) reported a positive allometric relationship (i.e. these authors found values of $b$ higher than three). According to Gurgel (2004), values of $b$ and weight and length parameters can vary between fishes of the same species, according to location, length and age of the population. Braga (1997) discussed the inverse relationship of constants $a$ and $b$ of the allometric equation, showing that the value of $b$ increases while the value of $a$, which is the condition factor, decreases. This indicates that it cannot be assumed as a constant condition; instead, it must be understood as a condition of that moment. Fishes condition can vary depending on reproductive cycle, food and other reasons (Braga, 1997).

A total of 11 stomachs were analyzed and eight food items were identified in the diet of $S$. heterodon. Insects fragments was the most consumed item $(\mathrm{GPA}=1.73)$ followed by microcrustaceans (Cladocera and Ostracoda), algae (mainly diatoms) and Odonata nymphs (Aeshnidae) (Table 1). The remaining items were recorded in smaller proportions. The items were classified as autochthonous origin, except fragments of insects, vegetal and animal matter (uncertain origin). The importance of autochthonous items for small fishes associated to macrophytes was recorded by Casatti et al. (2003) in Rosana reservoir at Paranapanema River (SP). According to the authors, there is high availability of detritus and periphyton in macrophytes banks which serves

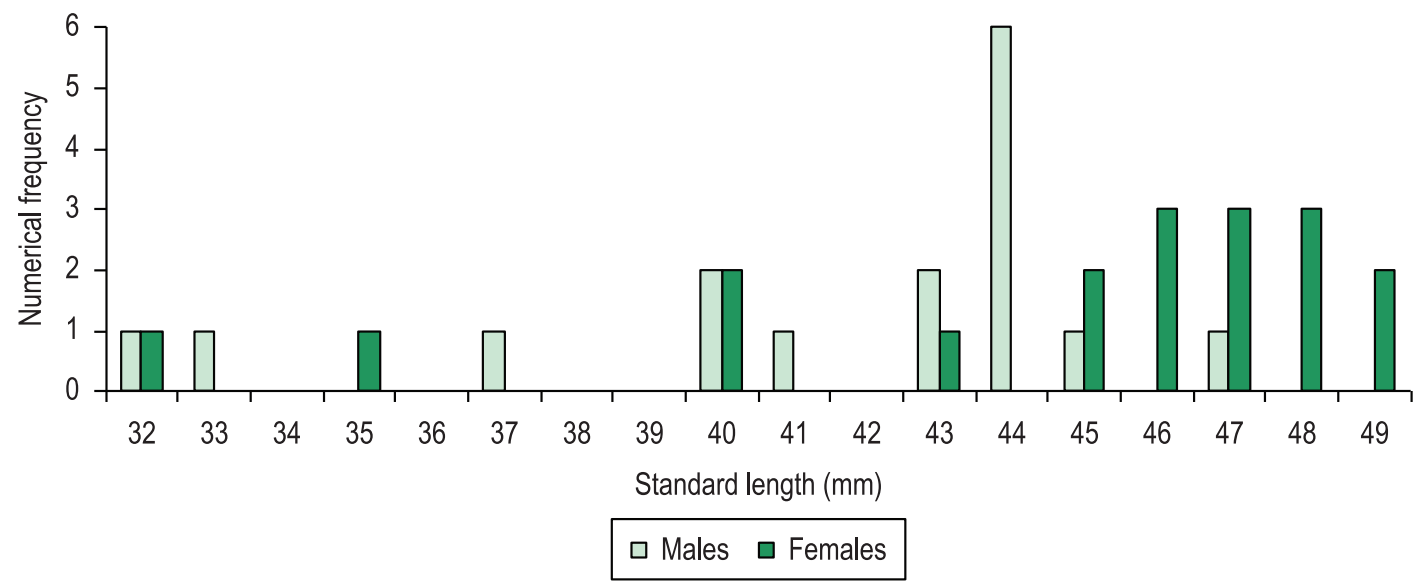

Figure 1. Standard length $(\mathrm{mm})$ distribution of Serrapinnus heterodon individuals (males and females), from Mogi Guaçu reservoir. 
Table 1. Classification of food items consumed by Serrapinnus heterodon from Mogi Guaçu reservoir.

\begin{tabular}{llrrrl}
\hline \multicolumn{1}{c}{ Food item } & $\mathrm{n}$ & $\%$ & $\mathrm{Si}$ & $\mathrm{GPA}$ & Classification \\
\hline Algae & 3 & 27.3 & 7 & 0.64 & Occasional \\
Macrophyte & 1 & 9.1 & 2 & 0.18 & Occasional \\
Vegetal matter & 2 & 18.2 & 2 & 0.18 & Occasional \\
Microcrustaceans & 6 & 54.5 & 9 & 0.82 & Occasional \\
Diptera (larvae) - Chironomidae & 1 & 9.1 & 1 & 0.09 & Occasional \\
Odonata (nymph) - Aeshnidae & 1 & 9.1 & 3 & 0.27 & Occasional \\
Insect (fragments) & 7 & 63.6 & 19 & 1.73 & Secondary \\
Animal matter & 1 & 9.1 & 2 & 0.18 & Occasional \\
\hline
\end{tabular}

$G P A=S i / N ; \mathrm{N}=11 ; \mathrm{n}=$ number of stomachs containing item $\mathrm{i} ; \%=$ frequency of occurrence of the item; $\mathrm{Si}=$ sum of the values assigned to each item $\mathrm{i}, \mathrm{N}=$ number of stomachs examined.

as food for autochthonous insects. Pelicice and Agostinho (2006) recorded items of autochthonous origin in the diet of 10 fish species associated to Egeria spp. patches in the same reservoir. These banks also function as microhabitat for small fishes to forage and as substrate for invertebrates, like microcrustaceans and insect larvae and nymphs (Winemiller and Jepsen, 1998). Esteves (2000) recorded high densities of three species of cheirodontines (Holoshestes heterodon $=S$. heterodon, Odontostilbesp. and Cheirodon stenodon $=$ O. stenodon (Eigenmann, 1915) in macrophytes banks in an oxbow lake of Mogi River (SP) (located downstream of the reservoir of the present study), suggesting that this may reflect a complex interaction between these fishes and aquatic vegetation. The item macrophyte was recorded in only one stomach of $S$. heterodon $(\mathrm{GPA}=0.18)$, and probably this was an accidental ingestion while taking other food items (insects or microcrustaceans) associated to aquatic vegetation.

Based on tooth morphology, Malabarba (2003) classified Cheirodontinae species as mainly herbivores, which was confirmed in the studied reservoir to $S$. heterodon with the high value of intestinal quotient obtained $(0.62 \mathrm{~mm})$. Nevertheless, the consumption of vegetal and animal items in similar proportions allows the classification of $S$. heterodon also as an omnivorous species. Gomiero and Braga (2008), in lotic rivers of São Paulo State and Dias and Fialho (2009), in the Ceará Mirim River (RN), also classified $S$. heterodon as omnivorous species. Alvim et al. (1998) classified this species as zooplanktivorous due to high consumption of cladocerans and Esteves (2000) as algivores, because of the predominance of filamentous algae. As in the present study, these authors also reported a reduced food spectrum for $S$. heterodon reflecting a diet with consumption of the items available in larger amounts in each environment.

Food items similar to those recorded here to $S$. heterodon were found in the diet of other cheirodontine species, differing only in the frequency they were ingested (Alvim et al., 1998; Luiz et al., 1998; Oliveira et al., 2001; Casatti et al., 2003; Hahn and Loureiro-Crippa, 2006; Pelicice and Agostinho, 2006; Hirano and Azevedo, 2007; Dias and Fialho, 2009; Santana-Porto and Andrian, 2009; Brandão-Gonçalves et al., 2010). Variations on food resource availability can lead to changes in frequency or quantity of items consumed by fishes (Deus and Petrere Junior, 2003).

As all specimens were found associated with marginal aquatic vegetation in the present study, it is assumed that $S$. heterodon uses these macrophytes as feeding sites and shelter from predators. Piana et al. (2006) studying $S$. notomelas populations in four ponds of Paraná River floodplain (PR/MS) found that predation was the main biotic factor regulating population size. It seems that the same did not occur in the reservoir of the present study, although six fish species (Oligosarcus pintoi Amaral Campos, 1945, Serrasalmus maculatus Kner, 1858, Gymnotus carapo Linnaeus, 1758, Hoplias malabaricus (Bloch, 1794), Astyanax altiparanae Garutti \& Britski, 2000 and Hoplosternum littorale (Hancock, 1828) consumed fishes preferential or occasionally in the same reservoir (C. S. Gonçalves, unpublished data). None of these species fed of $S$. heterodon in reservoir, but in oxbow lakes of Mogi Guaçu River located downstream of this reservoir, individuals of $S$. notomelas were found in the stomachs of H. malabaricus (Gonçalves, 2007). Thus, the presence of potential predators in reservoir does not seem to affect the occurrence of $S$. heterodon, which uses macrophytes as a refuge. In addition, another feature already mentioned about reservoir is the low 
water transparency, a factor that possibly helps the prey to hide from predators. Associations between fish and macrophytes in lentic environments were verified in several studies (Esteves, 2000; Meschiatti et al., 2000; Oliveira et al., 2001; Casatti et al., 2003; Petry et al., 2003; Pelicice and Agostinho, 2006; Hahn and Loureiro-Crippa, 2006), as in the present study.

The absolute fecundity of $S$. heterodon was estimated analyzing 10 pairs of mature gonads (stage $\mathrm{C})$, obtained in October $(\mathrm{n}=5)$ and February $(\mathrm{n}=5)$. The total number of oocytes ranged from 491 to 1,892 (mean $=1,231 \pm 440)$, and the number of mature oocytes ranged from 259 to $841($ mean $=568 \pm 204)($ Table 2$)$. The fecundity of $S$. heterodon found in the present study can be considered high, comparing with the results found in other cheirodontines as Serrapinnus calliurus (Boulenger, 1900) with fecundity of 426 oocytes (Gelain et al., 1999), Compsura heterura Eigenmann, 1915 with fecundity of 434 oocytes (Oliveira et al., 2010), Serrapinnus piaba (Lütken 1875) with fecundity of 441 oocytes (Silvano et al., 2003), Cheirodon ibicuhiensis Eigenmann, 1915 with fecundity of 513 oocytes (Oliveira et al., 2002) and Odontostilbe pequira with fecundity of 795 oocytes (Oliveira et al., 2010). Azevedo et al. (2010) found an average fecundity of 191 oocytes (range of 98 to 260), one of the lowest among characins, to Macropsobrycon uruguayanae Eigenmann, 1915 in Ibicuí River, Uruguay River basin (RS). These studies presented fecundity as the total number of vitellogenic oocytes, but only ripe oocytes are considered ready to be eliminated. Nevertheless, such differences, comparing the fecundity of these cheirodontines species with the results obtained herein to $S$. heterodon, should reflect a particular characteristic of each species according to their reproductive strategies, which can also differ among environments. All these studies involving fecundity of cheirodontines were conducted in lotic environments (rivers and "arroios"), whereas the present study were conducted in a lentic environment (reservoir), in places where aquatic vegetation were abundant on margins. Rozas and Odum (1988) conducted field experiments and observed that fecundity can be higher in fishes associated to vegetated areas.

The diameter of oocytes in $S$. heterodon ranged from 61 to $793 \mu \mathrm{m}$. Information about the size of mature oocytes in cheirodontines is scarce in the literature. One study, Azevedo et al. (2010), found the range of 405.6 to $1,014 \mu \mathrm{m}$ to $M$. uruguayanae.
Relating these results to the fecundity of these two species, we observed that $M$. uruguayanae have larger oocytes whereas $S$. heterodon has higher fecundity. These information are important to understand the reproductive tactics which comprises reproductive strategies of fish species and, unfortunately, only M. uruguayanae (Azevedo et al., 2010) has such information among Cheirodontinae to compare with our findings. According to Winemiller (1989), some species produce fewer and big yolk-rich oocytes, to increase the chance of survival of larvae, while others invest in lower production of oocytes, but in larger quantity. Serrapinnus heterodon fits into the second tactic, while $M$. uruguayanae into the first and the fact that this is an inseminating cheirodontine supports this statement.

The ovaries of teleost fishes present gametes in different and successive stages of development, which will characterize the spawning type of the species (Wallace and Selman, 1981). Of these, the most common spawning types in fishes of the upper Paraná River basin are synchronous in two groups (total) and synchronous in more than two groups (parceled) (Vazzoler and Menezes, 1992). The developmental stage of oocytes during the progressive accumulation of yolk into the final process of maturation of the ovaries is evidenced by gonadosomatic relationship (GSR) (West, 1990). Therefore, associating the development of oocytes in the ovaries and the degree of this development, we can follow the process of maturation of the ovaries and determine the spawning type.

The frequency distribution of oocytes diameters were made for each pair of ovaries and grouped according to its similarity of distribution, which

Table 2. Ovaries groups (according to oocytes diameters distribution), oocytes from initial ripening phase (N'), ripe oocytes $(\mathrm{N})$ and values of gonadosomatic relation (GSR) of Serrapinnus heterodon from Mogi Guaçu reservoir.

\begin{tabular}{cccc}
\hline Groups & $N^{\prime}$ & N & GSR $(\%)$ \\
\hline 1 & 491 & 285 & 7.2 \\
1 & 953 & 505 & 8.2 \\
1 & 1,363 & 259 & 9.9 \\
1 & 1,312 & 604 & 10.7 \\
1 & 977 & 703 & 14.3 \\
1 & 998 & 389 & 14.4 \\
1 & 1,659 & 763 & 14.9 \\
1 & 1,738 & 591 & 15.3 \\
1 & 1,892 & 738 & 21.3 \\
2 & 924 & 841 & 21.4 \\
Mean ( \pm sd) & $1,231( \pm 440)$ & $568( \pm 204)$ & \\
\hline
\end{tabular}


resulted in two groups (Figure 2). Analyzing Figure 2, it was observed ovaries in early stages of maturation (group 1) and one ovary ready to eliminate the oocytes during the spawning season (group 2). The presence of a single mode in the distribution of oocytes diameter suggests a total spawning. The high value of the GSR assigned to group $2(G S R=21.4)$, supports its advanced ovarian development compared to ovaries from group 1 $($ GSR mean $=12.9 \pm 4.4 \mathrm{sd})$ (Table 2). Azevedo et al. (2010) also found just one batch of mature oocytes, indicating a total spawning for $M$. uruguayanae. Total spawning occurs in species in which the period of larval development happens in a short time when the larvae starts to use the exogenous food supply and environmental conditions available after consuming the yolk from the yolk sac. Otherwise, parceled spawning is a reproductive tactic associated with environments that are stable for a longer period and without a large food supply for larvae hatched in the successive spawnings (Nikolsky, 1963, 1969). The breeding season for most fish from the upper Paraná River basin begins in October and continues
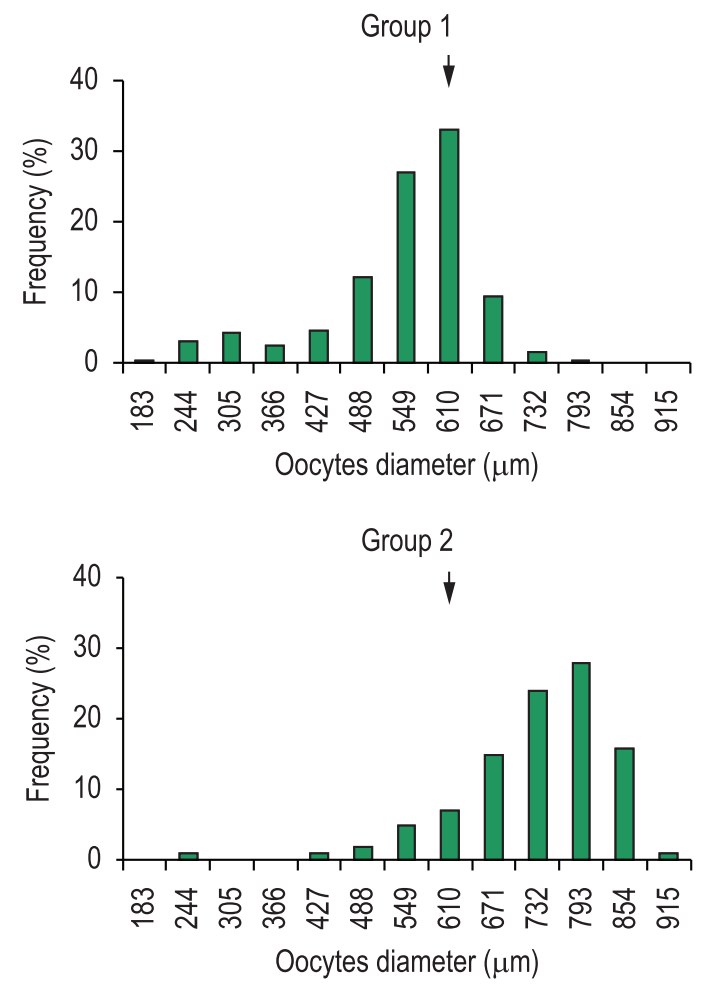

Figure 2. Frequency (\%) distribution of oocytes diameters of Serrapinnus heterodon, from Mogi Guaçu reservoir. Arrows indicate the size from which the oocytes are mature and ready to be eliminated during spawning. Group 1: oocytes in early stages of maturation; and Group 2: oocytes in last stages of maturation. until March, but is more concentrated in a period which coincides with the peak of the rainy season (December-January) (Vazzoler and Menezes, 1992). The majority of fish species presents a reproductive periodicity, starting the gonadal development in a time prior to the reproduction, completing its maturation at a time when environmental conditions are suitable for fertilization and development of offspring (Vazzoler, 1996).

Most specimens of $S$. heterodon were captured in feeding activity: $63 \%$ of stomachs were partially filled with food $(S R=2)$ and $29 \%$ were full $(S R=3)$. Regarding the accumulation of fat on visceral cavity, most specimens had low-fat accumulation ( $73 \%$ to $\mathrm{FA}=1$ and $21 \%$ to $\mathrm{FA}=2$ ). Concerning gonadal maturation, $65 \%$ of individuals presented mature gonads (stage $\mathrm{C}$ ) and 35\% was maturing or resting (stage B). Thus, it can be concluded that these individuals were preparing for the next breeding season. In fish, the seasonal cycle of nutritional reserves, such as fat accumulation, follows a pattern associated with reproduction. During reproduction, fish reduces feeding activity and uses energy reserves stored in fat for gonadal maturation (Nikolsky, 1963). Silvano et al. (2003) and Oliveira et al. (2010) determined that the reproductive period of two cheirodontines, S. piaba and Compsura heterura, respectively, lasted between January and April, corroborating our findings to S. heterodon. Moreover, Gomiero and Braga (2007) established that $S$. heterodon had massive spawn and it occurred in a short time (December). Although Gelain et al. (1999) and Oliveira et al. (2002) found a larger reproductive period to $S$. calliurus and Cheirodon ibicuhiensis, respectively, in a stream in southern Brazil (RS), they highlighted that it was concentrated on spring and summer months (rainy season). Despite these studies have been developed in different regions of Brazil, it is known that fish reproduction is usually associated with increases of rainfall during the rainy season when food availability to offspring is higher (Vazzoler and Menezes, 1992).

Males and females of $S$. heterodon, were found in similar proportion (1:1), despite females were predominantly larger than males. Since the sampling effort was standardized and constant and even so few individuals were caught, it is possible that the species is at low density in the study area. Few ecological studies were conducted with this cheirodontine species, probably because of this. The diet presented herein by $S$. heterodon (omnivorous, with a predominance of animal 
items of autochthonous origin) and reproductive strategy (total spawn during the rainy season, higher fecundity and smaller oocytes in comparison with other cheirodontine), were closely associated with marginal aquatic vegetation. The results seem to reflect the type of environment in which $S$. heterodon inhabit, because the lentic environment afforded by the dam provides good conditions to maintaining this species, which uses macrophytes as shelter from predators and as feeding and breeding sites.

\section{Acknowledgements}

We are grateful to Prof. Dr. Francisco Langeani for the identification of specimens, IBAMA for collection permits (02027.000991/2005-71), CAPES for mastership fellowship granted to the first author and two anonymous referees for improving the manuscript.

\section{References}

ALVIM, MCC., MAIA-BARBOSA, PM. and ALVES, CBM. 1998. Feeding of Holoshesthes heterodon Eigenmann (Teleostei, Cheirodontinae) of the Cajuru reservoir (Minas Gerais, Brazil), in relation to the vegetal biomass on its depletion zone. Revista Brasileira de Zoologia, vol. 15, no. 4, p. 955-1002.

AGOSTINHO, AA., GOMES, LC. and PELICICE, FM. 2007. Ecologia e manejo de recursos pesqueiros em reservatórios do Brasil. Maringá: EDUEM. 501 p.

ANDRADE, VXL., CAMPOS, FFS., LANGEANI, F. and ROMAGOSA, E. 2008. Reproductive dynamics of the main species of fish in the municipal reservoir of São José do Rio Preto. Boletim do Instituto de Pesca, vol. 34, no. 3, p. 365-373.

AZEVEDO, MA., MALABARBA, LR. and BURNS, JR. 2010. Reproductive biology and development of gill glands in the inseminating characid, Macropsobrycon uruguayanae Eigenmann, 1915 (Cheirodontinae: Compsurini). Neotropical Ichthyology, vol. 8, no. 1, p. 87-96. http://dx.doi.org/10.1590/S167962252010005000004

BARBIERI, G, PERET, AC. and VERANI, JR. 1994. Notas sobre a adaptação do trato digestivo ao regime alimentar em espécies de peixes da regiáo de São Carlos (SP). I. Quociente Intestinal. Revista Brasileira de Biologia, vol. 54, no. 1, p. 63-69.

BENITEZ, RS. and SÚAREZ, YR. 2009. Biologia populacional de Serrapinnus notomelas (Eingenmann, 1915) (Characiformes, Cheirodontinae) em um riacho de primeira ordem na bacia do rio Dourados, Alto rio Paraná. Pan-American Journal of Aquatic Sciences, vol. 3, no. 4, p. 271-278.

BORROR, DJ. and DELONG, DM. 1969. Introdução ao estudo de insetos. São Paulo: Edgard Blücher Ltda. $653 \mathrm{p}$.
BRAGA, FMS. 1990. Aspectos da reproduçáo e alimentaçáo de peixes comuns em um trecho do rio Tocantins entre Imperatriz e Estreito, Estados do Maranhão e Tocantins, Brasil. Revista Brasileira de Biologia, vol. 50, no. 3, p. 547-558.

BRAGA, FMS. 1997. Análise da equação alométrica na relação peso e comprimento e o fator de condição em Plagioscion squamosissimus (Teleostei, Sciaenidae). Revista Brasileira de Biologia, vol. 57, no. 3, p. 417-425.

BRAGA, FMS. 1999. O grau de preferência alimentar: um método qualitativo e quantitativo para o estudo do conteúdo estomacal de peixes. Acta Scientiarum, Biological Science, vol. 21, no. 2, p. 291-295.

BRANDÁO-GONÇALVES, L., OLIVEIRA, SA. and LIMA-JUNIOR, SE. 2010. Hábitos alimentares da ictiofauna do córrego Franco, Mato Grosso do Sul, Brasil. Biota Neotropica, vol. 10, no. 2, p. 21-30.

BUCKUP, PA., MENEZES, NA. and GHAZZI, MS. 2007. Catálogo das espécies de peixes de água doce do Brasil. Rio de Janeiro: Museu Nacional. 195 p.

CASATTI, L., MENDES, HF. and FERREIRA, KM. 2003. Aquatic macrophytes as feeding site for small fishes in the Rosana reservoir, Paranapanema river, southeastern Brazil. Revista Brasileira de Biologia, vol. 63, no. 2, p. 213-222.

CAVENAGHI, AL., VELINI, ED., NEGRISOLI, E., CARVALHO, FT., GALO, MLBT., TRINDADE, MLB., CORREA, MR. and SANTOS, SCA. 2005. Monitoramento de problemas com plantas aquáticas e caracterização da qualidade de água e sedimento na UHE Mogi-Guaçu. Planta Daninha, vol. 23, no. 2, p. 225-231.

DELARIVA, RL., AGOSTINHO, AA., NAKATANI, K. and BAUMGARTNER, G. 1994. Ichthyofauna associated to aquatic macrophytes in the upper Paraná River floodplain. Revista UNIMAR, vol. 16, no. 3, p. 41-60.

DEUS, CP. and PETRERE JUNIOR, M. 2003. Seasonal diet shifts of seven fish species in an Atlantic rainforest stream in southeastern Brazil. Brazilian Journal of Biology, vol. 63, no. 4, p. 579-588.

DIAS, TS. and FIALHO, CB. 2009. Biologia alimentar de quatro espécies simpátricas de Cheirodontinae (Characiformes, Characidae) do rio Ceará Mirim, Rio Grande do Norte. Iheringia, Série Zoologia, vol. 99, no. 3, p. 242-248.

ESTEVES, KE. 2000. Interação peixes-perifíton em uma lagoa marginal do Rio Mogi-Guaçu (SP): uma abordagem experimental. In SANTOS, JE. and PIRES, JSR., eds. Estudos integrados em ecossistema: Estação Ecológica de Jataí. São Carlos: RIMA Editora. p. 851-867.

GELAIN, D., FIALHO, CB. and MALABARBA, LR. 1999. Biologia reprodutiva de Serrapinnus calliurus (Characidae, Cheirodontinae) do arroio Ribeiro, 
Barra do Ribeiro, Rio Grande do Sul, Brasil. Comunicaçóes do Museu de Ciências e Tecnologia PUCRS, Série Zoologia, vol. 12, p. 71-82.

GOMIERO, LM. and BRAGA, FMS. 2007. Reproduction of a fish assemblage in the state of São Paulo, southeastern Brazil. Brazilian Journal of Biology, vol. 67, no. 2, p. 283-292.

GOMIERO, LM and BRAGA, FMS. 2008. Feeding habits of the ichthyofauna in a protected area in the state of Sáo Paulo, southeastern Brazil. Biota Neotropica, vol. 8, no. 1, p. 41-47.

GONÇALVES, CS. 2007. Biologia alimentar da ictiofauna na área de influência do reservatório da usina Mogi Guaçu e lagoas marginais da Estação EcológicaFazenda Campininha (SP). Rio Claro: Universidade Estadual Paulista. [Dissertaçáo de Mestrado em Zoologia].

GONÇALVES, CS. and BRAGA, FMS. 2008. Diversidade e ocorrência de peixes na área de influência da UHE Mogi Guaçu e lagoas marginais, bacia do alto Rio Paraná, São Paulo, Brasil. Biota Neotropica, vol. 8, no. 2, p. 103-114.

GURGEL, HCB. 2004. Estrutura populacional e época de reproduçáo de Astyanax fasciatus (Cuvier) (Characidae, Tetragonopterinae) do Rio Ceará Mirim, Poço Branco, Rio Grande do Norte, Brasil. Revista Brasileira de Zoologia, vol. 21, no. 1, p. 131-135. http://dx.doi.org/10.1590/S010181752004000100022

HAHN, NS. and LOUREIRO-CRIPPA, VE. 2006. Estudo comparativo da dieta, hábitos alimentares e morfologia trófica de duas espécies simpátricas, de peixes de pequeno porte, associadas às macrófitas aquáticas. Acta Scientiarum, Biological Science, vol. 28 , no. 4, p. 359-364.

HIRANO, RF. and AZEVEDO, MA. 2007. Hábito alimentar de Heterocheirodon yatai (Teleostei, Characidae, Cheirodontinae) de dois tributários do rio Ibicuí, Rio Grande do Sul, Brasil. Biociências, vol. 15 , no. 2, p. 207-220.

LANGEANI, F., CASTRO, RMC., OYAKAWA, OT., SHIBATTA, OA., PAVANELLI, CS. and CASATTI, L. 2007. Diversidade da ictiofauna do Alto Rio Paraná: composição atual e perspectivas futuras. Biota Neotropica, vol. 7, no. 3, p. 181-197. http://dx.doi. org/10.1590/S1676-06032007000300020

LIZAMA, MAP. and AMBRÓSIO, AM. 1999. Relação peso-comprimento e estrutura da população de nove espécies da família Characidae na planície de inundação do alto rio Paraná, Brasil. Revista Brasileira de Zoologia, vol. 16, no. 3, p. 779-788.

LOURENÇO, LS., SÚAREZ, YR. and FLORENTINO, AC. 2008. Aspectos populacionais de Serrapinnus notomelas (Eigenmann, 1915) e Bryconamericus stramineus Eigenmann, 1908 (Characiformes: Characidae) em riachos da bacia do rio Ivinhema,
Alto Rio Paraná. Biota Neotropica, vol. 8, no. 4, p. 43-49.

LOWE-McCONNELL, RH. 1975. Fish communities in tropical freshwaters: their distribution, ecology and evolution. London: Longman Inc. 337 p.

LUIZ, EA., AGOSTINHO, AA., GOMES, LC. and HAHN, NS. 1998. Ecologia trófica de peixes em dois riachos da Bacia do Rio Paraná. Revista Brasileira de Biologia, vol. 58, no. 2, p. 273-285.

MALABARBA, LR. 2003. Subfamily Cheirodontinae (Characins, tetras). In REIS, RR., KULLANDER, SO. and FERRARIS JUNIOR, CJ., orgs. Check List of the Freshwater Fishes of South and Central America. Porto Alegre: EDIPUCRS. p. 215-221.

MESCHIATTI, AJ., ARCIFA, MS. and FENERICHVERANI, N. 2000. Fish communities associated with macrophytes in Brazilian floodplain lakes. Environmental Biology of Fishes, vol. 58, p. 133-143. http://dx.doi.org/10.1023/A:1007637631663

NEEDHAM, JG. and NEEDHAM, PR. 1982. Guia para el studio de los seres vivos de las aguas dulces. Barcelona: Reverte. 131 p.

NIKOLSKII, GV. 1969. Theory of fish population dynamics: as the biological background for rational exploitation and management of fishery resources. Edinburgh: Oliver and Boyd Ltd. 321 p.

NIKOLSKY, GV. 1963. The ecology of fishes. London: Academic Press. 353 p.

OLIVEIRA, AK. and GARAVELLO, JC. 2003. Fish assemblage composition in a tributary of the MogiGuaçu River basin, southeastern Brazil. Iheringia, Série Zoologia, vol. 93, no. 2, p.127-138.

OLIVEIRA, CLC., FIALHO, CB. and MALABARBA, LR. 2002. Período reprodutivo, desova e fecundidade de Cheirodon ibicuhiensis Eigenmann, 1915 (Ostariophysi: Characidae) do arroio Ribeiro, Rio Grande do Sul, Brasil. Comunicaçôes do Museu de Ciências e Tecnologia PUCRS, Série Zoologia, vol. 15, no. 1, p. 3-14.

OLIVEIRA, CLC., FIALHO, CB. and MALABARBA, LR. 2010. Reproductive period, fecundity and histology of gonads of two cheirodontines (Ostariophysi: Characidae) with different reproductive strategies - insemination and external fertilization. Neotropical Ichthyology, vol. 8, no. 2, p. 351-360. http://dx.doi.org/10.1590/S167962252010000200014

OLIVEIRA, EF., LUIZ, EA., AGOSTINHO, AA. and BENEDITO-CECÍLIO, E. 2001. Fish assemblages in littoral areas of the upper Paraná river floodplain, Brazil. Acta Scientiarum. Biological Science, vol. 23, no. 2, p. 369-376.

PELICICE, FM. and AGOSTINHO, AA. 2006. Feeding ecology of fishes associated with Egeria spp. patches in a tropical reservoir, Brazil. Ecology of Freshwater Fish, 
vol. 15, p. 10-19. http://dx.doi.org/10.1111/j.16000633.2005.00121.x

PEREZ JUNIOR, OR. and GARAVELLO, JC. 2007. Ictiofauna do ribeirão do Pântano, afluente do rio Mogi-Guaçu, bacia do alto rio Paraná, São Paulo, Brasil. Iheringia, Série Zoologia, vol. 97, no. 3, p. 328-335.

PETRY, P., BAYLEY, PB. and MARKLE, DF. 2003. Relationships between fish assemblages macrophytes and environmental gradients in the Amazon River floodplain. Journal of Fish Biology, vol. 63, p. 547-579. http://dx.doi.org/10.1046/j.10958649.2003.00169.x

PIANA, PA., GOMES, LC. and CORTEZ, EM. 2006. Factors influencing Serrapinnus notomelas (Characiformes: Characidae) populations in upper Paraná river floodplain lagoons. Neotropical Ichthyology, vol. 4, no. 1, p. 81-86.

ROZAS, LP. and ODUM, WE. 1988. Occupation of submerged aquatic vegetation by fishes: testing the roles of food and refuge. Oecologia, vol. 77, no. 1, p. 101-106. http://dx.doi.org/10.1007/BF00380932

SANTANA-PORTO, EA. and ANDRIAN, IF. 2009. Trophic organization the ichthyofauna of two semilentic environments in a floodplain on the upper Paraná River, Brazil. Acta Limnologica Brasiliensia, vol. 21, no. 3, p. 359-366.

SIlVANO, J., OLIVEIRA, ClC., FIALHO, CB. and GURGEL, HCB. 2003. Reproductive period and fecundity of Serrapinnus piaba (Characidae: Cheirodontinae) from the rio Ceará Mirim, Rio Grande do Norte, Brazil. Neotropical Ichthyology, vol. 1, no. 1, p. 61-66. http://dx.doi.org/10.1590/ S1679-62252003000100007

VAZZOLER, AEAM. 1996. Biologia da reprodução de peixes teleósteos: teoria e prática. Maringá: EdUEM. $169 \mathrm{p}$.

VAZZOLER, AEAM. and MENEZES, NA. 1992. Síntese de conhecimentos sobre o comportamento reprodutivo dos Characiformes da América do Sul (Teleostei, Ostariophysi). Revista Brasileira de Biologia, vol. 52, no. 4, p. 627-640.

WALLACE, RA. and SELMAN, K. 1981. Cellular and dynamic aspects of oocyte growth in teleosts. American Zoologist, vol. 21, p. 325-343.

WALTER, H. and LIETH, H. 1960. KlimadiagrammWeltatlas. VEB Gustav Fischer Verlag Jena.

WELCOMME, RL. 2002. An evaluation of tropical brush and vegetation park fisheries. Fisheries Management and Ecology, vol. 9, no. 3, p. 175-188. http://dx.doi. org/10.1046/j.1365-2400.2002.00292.x

WEST, G. 1990. Methods of assessing ovarian development in fishes: a review. Australian Journal of Marine and Freshwater Research, vol. 41, no. 2, p. 199-222. http://dx.doi.org/10.1071/MF9900199

WINEMILLER, KO. 1989. Patterns of variation in life history among south american fishes in a seasonal environments. Oecologia, vol. 81, p. 225-241.

WINEMILLER, KO. and JEPSEN, DB. 1998. Effects of seasonality and fish movement on tropical river food webs. Journal of Fish Biology, vol. R3, supplement A, p. 267-296.

ZAR, JH. 2010. Biostatistical analysis. New Jersey: Prentice-Hall. 944 p. 